\title{
Hatékonyság és egyéniesítés a büntetőeljárásban Pecsenye Máté
}

\begin{abstract}
A különleges bánásmód és "távmeghallgatás" jogintézménye az új büntetöeljárási törvényben jelentös mértékben átalakult, éppen ezért vált indokolttá a büntetöeljárás hatékonyságának és az említett intézmények összefüggéseinek vizsgálata. Ennek megfelelöen cikkemben elemeztem a hazai büntetőeljárás hatékonyságát, időszerüségét, majd a különleges bánásmód és telekommunikációs eszköz használata föbb szabályainak elemzése által igyekeztem bemutatni, hogy ezen jogintézmények milyen formában és mennyiben képesek az eljárás hatékonyságát javítani, azt gyorsítani, egyszerüsíteni.
\end{abstract}

Kulcsszavak: büntetöeljárás, hatékonyság, egyéniesités, távmeghallgatás, különleges bánásmód

\section{Efficiency and individualization in the criminal procedure}

The legal institutions of special treatment and "remote hearing" have been significantly transformed in the new Criminal Procedure Act that is why it has become necessary to examine the context of those institutions and the effectiveness of criminal proceedings. Accordingly, in my article I studied the efficiency and timeliness of the domestic criminal proceedings and then I aimed to trace in what form and to what extent these legal institutions are able to speed up, simplify and improve the efficiency of the procedures.

Keywords: criminal procedure, efficiency, individualization, remote hearing, special treatment

DOI: $10.32980 / M J S z .2021 .1 .942$

"A szabály semmit sem ér, ha elhatározás-szerüen viseled, ha komoran és konokul csörömpöl rajtad; a szabály akkor jó, ha érzéseidbe ivódik és finoman, hajlékonyan támogat."

\section{Bevezetés}

5 z eljárásjogi kódexek a jogrendszer alappillérei, valamennyi jogalkalmazó O munkavégzését alapvetően befolyásolják. Ezen törvények szerepének jelentőségét tovább növeli, hogy az állampolgárok is ezen kódexek szabályaival találkoznak legsürübben, akár sértettként, tanúként kell megjelenniük a nyomozó hatóságon, ügyészségen, bíróságon, akár polgári, vagy közigazgatási jogi vitájukat kívánják a bíróság által rendezni.

A büntetőeljárási törvény az állami büntetőhatalom és a polgárok közvetlen kapcsolatát is alapvetően érinti, jogalkotóként és jogalkalmazóként egyaránt számolni kell azzal a szemponttal, hogy a társadalom minden korban növekvő

\footnotetext{
* Bírósági titkár, Miskolci Törvényszék.

${ }^{1}$ Weöres Sándor: A teljesség felé, Helikon Kiadó, Budapest, 2019, 65. oldal
} 
elvárásokat támaszt az emberi együttélés rendjét sértő és veszélyeztető bűncselekmények elleni állami fellépés minőségével szemben. ${ }^{2} \mathrm{~A}$ büntetőeljárásról alkotott ellentmondásos vélemények eloszlatása érdekében fontos olyan eljárásrend kialakítása, amely révén az állami szervek eljárásába vetett bizalom, illetve az igazságszolgáltatási szervek eljárásával kapcsolatos társadalmi elégedettség növelhető. Tény, hogy az igazságszolgáltatás minősége csak akkor javítható, ha a törvény megfelel a búnüldözéssel és az ítélkezéssel szemben megfogalmazott elvárásoknak.

Jelentős társadalmi igény mutatkozik továbbá az eljárások időszerű befejezése, továbbá a büntető igazságszolgáltatás hatékony müködése iránt. Ennek lényege, hogy a büncselekmények elkövetőit - de csak őket - kivétel nélkül, minél kevesebb társadalmi ráfordítás mellett, tisztességes eljárásban vonják felelősségre. Szükséges, hogy az állam kifejezze: a sérelmet szenvedett fél mellé áll, és a büntetőeljárás lefolytatását érdemben elősegítőkre is partnerként tekint. ${ }^{3}$

Éppen ezen okok miatt egy eljárási kódex - esetünkben a büntetőeljárási kodifikálásakor, az új szabályozás kialakítását meghatározó alapvető szempontok megalkotásakor a jogalkotónak ugyanakkora, ha nem nagyobb figyelmet kell fordítania az igazságszolgáltatással kapcsolatos társadalmi elvárásoknak való megfelelésre, mint a jogászi hivatásrendek jogalkalmazás során összegyüjtött tapasztalatai alapján felmerült igényekre vagy éppen Magyarország nemzetközi jogi és európai uniós tagságból fakadó kötelezettségeire.

$\mathrm{Az}$ imént kifejtettekre is figyelemmel a büntetőeljárásnak, és annak jogintézményeinek vizsgálata, elemzése során is aktuálisak Weöres Sándor fent idézett szavai, hiszen ahhoz, hogy a magyar büntetőeljárási kódex eleget tegyen a modern büntetőeljárásokkal szemben támasztott követelményeknek (hatékonyság, gyorsaság, egyszerűség, koherencia, célszerűség), nagy jelentőséggel bír a jogalkalmazók - a büntetőeljárás esetében bírák, ügyészek, nyomozóhatóság tagjai, védők - , és az eljárási törvénnyel találkozó állampolgárok - összefoglalóan a büntetőeljárásban részt vevő személyek - „szimpátiának elnyerése”, annak elérése, hogy a jogalkotó, a jogalkalmazó és a társadalom is hasznos és szükséges változásként tekintsen a kódex változásaira. ${ }^{4}$

A fenti idézet nem csupán a büntetőeljárásról szóló 2017. évi XC. törvény (Be.) átfogó vizsgálata esetén lehet találó, hanem a cikkem vizsgálatának tárgyát képező jogintézmények, a különleges bánásmód és a "távmeghallgatás" szabályainak elemzésekor is. Mindkét jogintézmény jelentős átalakuláson esett át, a Be. a korábbi szabályozáshoz képest jelentősen kiterjesztette mind a különleges bánásmódot igénylő eljárási résztvevők, mind a telekommunikációs eszköz alkalmazhatóságának körét. Véleményem szerint mindkét intézmény megfelelő alkalmazása esetén segíthet a kodifikáció során meghatározott irányelvek elérésében, azonban ehhez

${ }^{2}$ Igazságügyminisztérium előterjesztése az új büntetőeljárási törvény szabályozási elveiről, 2015. február 24., 8. oldal

3 A büntetőeljárásról szóló T/13972. számú törvényjavaslat miniszteri indokolása, Budapest, 2017. február, 317. oldal

${ }^{4}$ dr. Pecsenye Máté: Vádalku magyar módra - az előkészítő ülés, In: Miskolci Jogi Szemle, XIV. évfolyam, 2019, 1. szám 1. kötet, 148. o. 
szükséges a korábban említett jogalkalmazói, társadalmi támogatás, annak felismerése, hogy az új jogintézmények alkalmazása nem csupán a jogalkotó céljait, hanem a társadalom - büntetőeljárással szemben támasztott - elvárásait is hivatott és képes szolgálni.

A Be. 2018. július 1. napjával történő hatálybalépésére tekintettel mindkét, cikkem tárgyát képező jogintézménnyel kapcsolatos bírósági gyakorlat kialakulóban van, így az előbb említett „rokonszenv elnyerése” és a kodifikáció során lefektetett irányelveknek való megfelelés miatt is szükségesnek tartom bemutatni a hazai büntetőeljárás hatékonyságát. Ezt követően a különleges bánásmód biztosítása és a telekommunikációs eszköz használata szabályainak elemzése útján bemutatom, hogy megítélésem szerint ezen jogintézmények milyen formában képesek az eljárás hatékonyságát javítani, azt gyorsítani, egyszerűsíteni, költségeit csökkenteni.

\section{Hatékony büntetőeljárás}

2.1. A büntetőeljárás hatékonyságának meghatározása. $A z$ ideális büntetőeljárási jog megteremtése minden állam alapvetó érdeke, a társadalom elemi igénye az igazságszolgáltatás kiváló minősége, azaz annak követelménye, hogy a büncselekmény elkövetője kapja meg igazságos büntetését, de ártatlanokat ne ítéljenek el. ${ }^{5}$ Ugy gondolom, az minden gyakorló büntetőjogász és a társadalom egésze számára is egyértelmü, hogy ezen, fent említett követelmény maximális teljesítése utópisztikus elvárás, ám megítélésem szerint kísérletet kell tennünk a büntetőeljárás hatékonyságának definiálására, egy olyan meghatározás felállítására, amely képes az eljárás valamennyi résztvevőjének azon kívánalmait is figyelembe venni, ötvözni, amelyek nem feltétlenül harmonizálnak egymással. Annál is inkább fontos ezen definíció felállítása, mivel az alapvető jelentőséggel bír büntetőeljárási rendszerünk fejlesztésére nézve.

Az állam kötelessége egy olyan büntetőeljárás müködtetése, amely gyors, hatékony és költségkímélő. A társadalom igazságszolgáltatással szemben támasztott alapvető elvárásai között szerepel a gyorsaság mellett, és a költséghatékonyság helyett, hogy az a büncselekmények elkövetőivel szemben hatékonyan lépjen fel, az elkövetőt vonja felelősségre, a büncselekménnyel okozott kár megtérüljön és az elkövetők reintegrációját is segítse elő. ${ }^{6} \mathrm{~A}$ büncselekmény sértettjének igénye az elkövető megbüntetésén túl kárának minél hamarabbi és teljes megtérülése ${ }^{7}$, a terhelt elvárása, hogy a büntetőeljárás a lehető legrövidebb ideig tartson, és ügyében minél hamarabb döntés szülessen. Emellett ki kell emelnünk, hogy napjainkban a terhelt jogainak biztosítása és ezáltal a védelemhez való jog széles részjogosítványai a büntetőeljárás valamennyi szakaszát áthatják, egyes vélemények

${ }^{5}$ dr. Pápai-Tarr Ágnes: A büntetőeljárás gyorsításának lehetőségei a francia és a magyar jogban, PhD értekezés, Deák Ferenc Állam- és Jogtudományi Doktori Iskola, Miskolc, 2010, 17. oldal

${ }^{6}$ Kerezsi Klára: A közvélemény és a szakemberek a helyreállító igazságszolgáltatásról, In: Büntetőjogi Kodifikáció, 2006/2. szám, 8. oldal

${ }^{7}$ Róth Erika: A sértett szerepe a büntetőeljárásban - avagy mit kíván az Európai Unió?, In: Emlékkönyv Kratochwill Ferenc tiszteletére (Szerk.: Farkas Ákos) Bíbor Kiadó, Miskolc, 2003, 45. o. 
szerint veszélyeztetve az igazság felderítésének követelményét, és hozzájárulva az eljárások elhúzódásához. ${ }^{8} \mathrm{~A}$ terhelt büntetőeljárási érdekei vonatkozásában említést érdemel, hogy ellentmondás feszül az eljárás gyors elintézése és aközött, hogy az idő múlását a büntetés kiszabásakor általában enyhítő körülményként kell figyelembe vennie a bíróságnak ${ }^{9}$, ezáltal előfordulhat, hogy éppen a terhelti oldal perelhúzó magatartása áll a büntetőeljárások elhúzódása mögött. Mindazonáltal megítélésem szerint ezen perelhúzó magatartás az előbb hivatkozott Kúriai véleményre is figyelemmel megfelelően ellensúlyozható, hiszen az időmúlás enyhítő körülményének nyomatéka teljesen el is enyészhet abban az esetben, ha azt az elkövető idézte elő.

Mindezek alapján könnyen belátható, hogy nem egyszerü, talán lehetetlen feladat a büntetőeljárás résztvevőinek valamennyi igényét teljesíteni, azokat összehangolni. ${ }^{10}$ Ám annak ellenére, hogy a büntetőeljárás az összes szereplő igényét teljesíteni nem tudja, véleményem szerint két érdek - az alapvető eljárási garanciák megtartása és az eljárás gyorsítása, egyszerűsítése - között egyensúlyozva alkotható meg az ideális és hatékony büntetőeljárási jog.

Gyakran hangsúlyozott ellenérv a büntetőeljárás gyorsítása kapcsán, hogy az az eljárási garanciák egy részének elvesztésével és így az alapvető eljárási garanciák sérelmével jár, ám megítélésem szerint a büntetőeljárás hatékonysága szempontjából ugyanolyan fontos az eljárások elhúzódásának visszaszorítása, mint az eljárási garanciák megtartása. Ezt támasztja alá, hogy mind az emberi jogok és alapvető szabadságok védelméről szóló egyezmény 6. cikke, mind Magyarország Alaptörvénye a független és pártatlan bíróság, tisztességes és nyilvános tárgyalás garanciáival egy szinten említi az eljárások ésszerű időn belüli tárgyalását is. ${ }^{11}$

Ennek megfelelően a büntetőeljárás és annak hatékonysága szempontjából éppoly fontos az eljárások elhúzódásának visszaszorítása, mint az eljárási garanciák megtartása. Annál is inkább, mivel az eljárások elhúzódása nem csupán a terhelt, hanem az eljárás többi résztvevője számára is hátrányos. ${ }^{12}$

Emellett - utalva cikkem fó témájára, a különleges bánásmód és a távmeghallgatás szabályaira - fontosnak tartom kiemelni, hogy speciális probléma merül fel a gyermek sérelmére elkövetett büncselekmények esetén. Ezen cselekmények súlyosan traumatizálják az áldozatot, a büntetőeljárást ezért olyan feltételek megteremtésével kellene lefolytatni, amelyek lehetővé teszik az eljárásban részt vevő gyermekek újabb traumatizálódásának, másodlagos áldozattá válásának megelőzését, minimalizálását. ${ }^{13}$ Ugyanakkor ezen ügyek jellemzően bizonyítékhiányosak, a gyermek vallomása, az abból feltárható tények kiemelkedő fontosságúak a felderítésben és bizonyításban, így a gyermek meghallgatása mind

\footnotetext{
${ }^{8}$ dr. Pápai-Tarr Ágnes: i.m. 19. o.

${ }^{9}$ Kúria 56/2007. BK véleménye a büntetéskiszabás során értékelhető tényezőkről, III/10. pont

${ }^{10}$ Tóth Mihály: Erózió vagy kiteljesedés? Fundemantum, 2008/1. szám, 111. o.

${ }^{11}$ Magyarország Alaptörvénye (2011. április 25.) XVIII. cikk (1) bekezdés

12 Kiss Anna: A hazai büntetőeljárás hatékonyságáról, In: Vókó György (szerk.): Kriminológiai tanulmányok 53., Országos Kriminológiai Intézet, Budapest, 2016, 81. oldal

13 Parti Katalin - Solt Ágnes - Virág György: Gyermekkorúak meghallgatása a büntetőeljárás során Magyarországon az európai és nemzetközi standardok tükrében In: Vókó György (szerk.): Kriminológiai tanulmányok 55., Országos Kriminológiai Intézet, Budapest, 2018, 64. oldal
} 
az áldozat mentális egészsége, mind a bizonyítás szempontjából kulcsfontosságú. Éppen ezen nehézséget oldhatja meg a különleges bánásmódot igénylő személy (jelen esetben a tizennyolcadik életévét be nem töltött személy) telekommunikációs eszköz útján történő meghallgatása, hiszen véleményem szerint ily módon a büntetőeljárás gyorsítása és az áldozat kiemelt védelme egyaránt megvalósítható.

Ezen érvek mentén haladva a büntetőeljárás akkor lesz hatékony, ha egyensúlyoz a korábban már említett két alapvető érdek között, s az alapvető eljárási garanciák (ártatlanság vélelme, védelemhez füződő jog, bírósági eljáráshoz való jog) figyelembevétele mellett az eljárás egyszerüsítésére, gyorsítására törekszik.

2.2. A hatékonyság mérésének mutatói. A büntetőeljárás hatékonyságának definiálása után kulcsfontosságú annak vizsgálata, milyen eszközeink, mutatóink vannak e hatékonyság mérésével összefüggésben. Véleményem szerint a XX. és XXI. század kontinentális jogfejlődése azáltal, hogy jelentősen átalakította a hatékony büntetőeljárásról vallott nézeteinket, alapjaiban változtatta meg a hatékonyság mérésének mutatóit is. Jól példázza ezt, hogy azon 2002-es definíció, mely szerint "minél magasabb a felderített, minél alacsonyabb a felderítetlen büncselekmények száma, minél nagyobb a váderedményesség, minél több ügyet sikerül a bíróságnak elsö fokon fellebbezés nélkül lezárni a lehetö legrövidebb időn belül, de legalábbis a legkevesebb késedelemmel, annál nagyobb hatékonysággal dolgozik a büntetó igazságszolgáltatás'14, csupán a büntetőeljárás hatékonyságának egyik, kétségtelenül fontos, de nem kizárólagos részének, a büncselekmények felderítésének szempontjából vizsgálja azt. Ám a büntetőeljárás humanizálódásával és azzal, hogy az állami büntetőhatalom érvényesülése elé jelentős korlátokat állítottak, ma nem csupán a büntetőjogi felelősségről való döntés a büntetőeljárás célja, hanem azok alkotmányos, jogállami keretek között, az emberi jogokat tiszteletben tartva, a tisztességes eljárás keretei között történő felderítése. ${ }^{15}$

Mindezek alapján belátható, hogy a büntetőeljárás hatékonyságának mérése nem szükíthető le az időszerüség követelményének vizsgálatára, hiszen ezen cél elérése mellett ugyanolyan fontossággal bír az eljárás jogszerüsége és megalapozottsága. Ezen "hármas piramis" megfeleltethető a bíróság döntései iránt támasztott követelményeknek is, mivel az ítéleteknek is jogszerünek, megalapozottnak és időszerünek kell lenniük. ${ }^{16}$

Az imént említett "piramis" analógiája azért is találó a büntetőeljárás hatékonyságának elemzésekor, mivel annak ellenére, hogy a büntetőeljárás időszerűsége mennyiségi, míg annak jogszerűsége és megalapozottsága minőségi mutatókkal mérhető, e három mutató nem választható el egymástól, akármelyik mutató romlása a büntetőeljárás hatékonyságának másik két mutatójának és ezáltal a rendszer egészének romlását okozza. Könnyen felismerhető, hogy lehet a büntetőeljárás időszerü, a mennyiségi mutatók számára kielégítő, ha az nem megalapozott és nem jogszerü, akkor a büntetőeljárás nem teljesíti minőségi

14 Prof. Dr. Farkas Ákos - A falra akasztott nádpálca, avagy a büntető igazságszolgáltatás hatékonyságának korlátai, Osiris Kiadó, 2002, 122. o.

${ }^{15}$ Prof. Dr. Farkas Ákos - Dr. Róth Erika: A büntetőeljárás, Budapest, Complex kiadó, 2012, 25. oldal

${ }^{16}$ Dr. Répássy Árpád pályaműve a Miskolci Törvényszék elnöki állására kiírt pályázathoz, 2016. április 8. 10. oldal 
kritériumait, ezáltal nem látja el feladatát, a büncselekmények felderítését és a társadalom szolgálatát. Emellett belátható, ha az eljárás nem tesz eleget a jogszerűség és megalapozottság kritériumának, az hosszú távon - a másodfokú bíróság hatályon kívül helyező ítéletei, vagy bizonyítás felvételét elrendelő tevékenysége okán - az időszerüség mutatóját is negatív módon befolyásolja.

A büntetőeljárás időszerüsége mennyiségi (ügyérkezés, befejezésszám, folyamatban maradt ügyek száma, pertartamvizsgálat), míg annak jogszerüsége, megalapozottsága minőségi (fellebbezések aránya, felülbírálat során született döntések aránya) mutatókkal mérhető. Ám fontos kiemelni, hogy a két csoportnak van metszete, hiszen mindkét mutató adatai megjelennek az egész büntetőeljárás időtartamának vizsgálatakor. Ez azt határozza meg, hogy mennyi idő telik el a nyomozás elrendelésétől a jogerős bírósági határozat meghozataláig. Ezen mutató egyrészt a nyomozó hatóság, az ügyészség és a bíróság munkáját, mint egységes egészet értékeli, másrészt a jogerős döntés miatt - a másodfokú bíróság hatályon kívül helyező végzése folytán - megjelenik benne az ítélkezés megalapozottsága, jogszerüsége is.

A későbbiek során bővebben is kifejtem, de már itt utalok arra, hogy a különleges bánásmód és "távmeghallgatás" szabályainak alkalmazása megítélésem szerint egyéb lényeges előnyei (áldozatvédelem, költséghatékonyság) mellett - mind a büntetőeljárás mennyiségi, mind minőségi mutatóit javíthatja.

2.3. A hazai büntetőeljárás hatékonyságának konkrét adatai. $A z$ imént említett példálózó felsorolásból és az Országos Bírósági Hivatal által minden évben elkészített ügyforgalmi elemzésből ${ }^{17}$ is látható, hogy ezen mutatók teljes körű elemzése komplex feladat, így ezen alfejezetben néhány adat ismertetése által csupán szemléltetni igyekszem a hazai büntetőeljárás hatékonyságának helyzetét. Annál is inkább fontosnak tartok néhány adatot kiemelni, mivel a bevezetőben már említett, a kodifikáció során felmerülő társadalmi elvárásoknak való megfelelés igényéhez - jelen esetben a büntetőeljárás "gyorsaságához" - is közelebb kerülhetünk általa. A társadalom büntetőeljárás elhúzódásával kapcsolatos türelmetlensége akkor érthető igazán, ha az eljárás lassúsága tényekkel is igazolható. ${ }^{18}$

A rendelkezésre álló statisztikai adatok alapján a nyomozások átlagos időtartama a 2005-ös 159,2 napról 2013-ra 220,7 napra emelkedett. A bírósági eljárások időtartamának átlaga a vádemeléstől a jogerős határozatig számolva a 2005-ben mért 369,3 napról 2013-ra 410,7 napra növekedett. ${ }^{19}$ Mindezek alapján 2005-ben átlagosan 528,5 nap alatt fejeződött be jogerősen egy büntetőeljárás, ám ehhez 2013-ban már 631,4 nap kellett.

Meglátásom szerint az előző fejezetben kifejtettekre is tekintettel egyértelmü, hogy e két mutató összeadásával kapjuk a leghitelesebb képet a hazai büntetőeljárás

\footnotetext{
17 Országos Bírósági Hivatal - Ügyforgalmi elemzés 2019. I. félév

${ }_{18}$ Miskolczi Barna: A nyomozási határidő tervezett rendszere az új büntetőeljárási törvényben ;

https://jogaszvilag.hu/szakma/a-nyomozasi-hatarido-tervezett-rendszere-az-uj-buntetoeljarasitorvenyben/ (megtekintés ideje: 2019. november 23.)

${ }^{19}$ Elek Balázs: Költség és időtartalékok a büntetőeljárásban, In: Büntetőjogi Szemle, 2015/1-2. szám, 10. oldal
} 
hatékonyságáról, nem beszélve arról, hogy a terhelt, a büntetőeljárás résztvevői és a közvélemény számára is ez a legfontosabb: nem az érkezett, folyamatban maradt, vagy befejezett ügyek száma, de nem is a hatályon kívül helyezések száma, hanem az a perdöntő, hogy mennyi idő alatt és milyen eredménnyel zajlik le jogerősen egy büntetőeljárás.

Ezen adatból egyértelmúen látható, hogy a büntetőeljárások hossza 2005 és 2013 között - mind a nyomozati, mind a bírósági szakra visszavezethetően - jelentős mértékben megnövekedett, azaz a társadalom és a jogalkotó részéről is reális elvárás ennek csökkentése, a büntetőeljárás hatékonyságának javitása, annak gyorsítása. Az vitán felül áll, hogy a mutató javításához nem elégséges a jogalkotói és jogalkalmazói szándék, ahhoz a büntetőeljárás rendszerének jelentős megújítása szükséges.

Tekintettel arra, hogy az új büntetőeljárási kódex hatályba lépése óta mindössze alig több, mint 2 év telt el, tendenciát felfedezni és mélyreható elemzést végezni a büntetőeljárás hatékonyságának változása terén nem lehet.

\section{A befejezés átlagos időtartama járásbírósági szinten büntetö ügyszakban (napokban)}

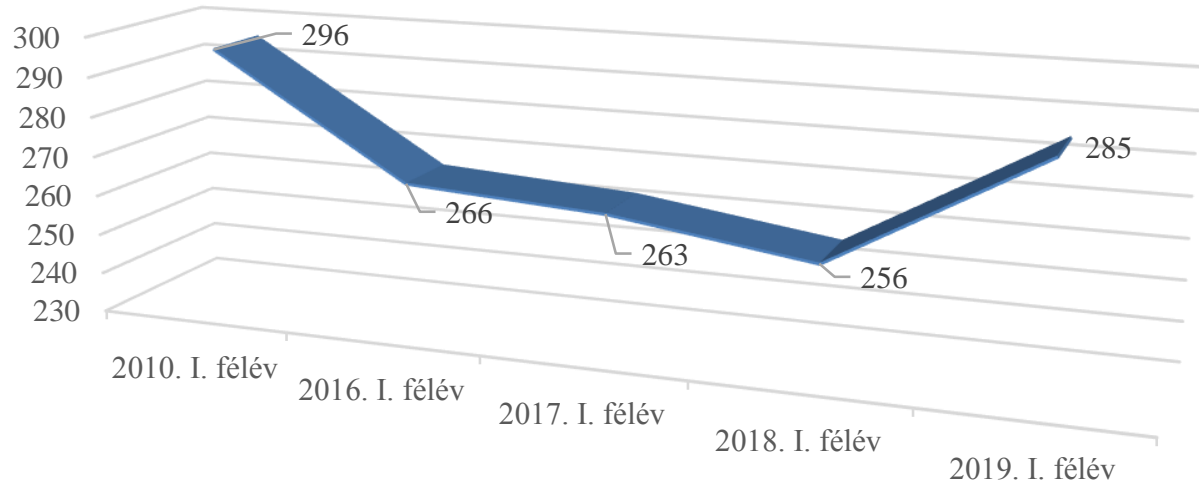

1. ábra: A befejezés átlagos időtartama járásbírósági szinten (napokban) büntető ügyszakban

Ám érdekes megfigyelni, hogy a legfrissebb, 2019-es adatok (a 2020-as ügyforgalmi elemzés nem tartalmaz ilyen adatot, ám a kialakult járványügyi helyzetre tekintettel annak vizsgálata sem lenne releváns) alapján a peres ügyek járásbírósági szinten való befejezésének átlagos időtartama büntető ügyszakban - az előző évek javulásával ellentétben - jelentős mértékben megnövekedett. Ezen növekedést azonban magyarázza, hogy a mutató alakulását kedvezőtlenül befolyásolta a peres érkezés jelentős visszaesése; azaz a frissen érkezett, rövid pertartamú, átlagokat javitó ügyek csökkenése, mely járásbírósági büntető ügyeknél drasztikus mértékü (38\%) volt. 
Ezen ábrával és összefüggéssel is azt kívánom érzékeltetni, hogy a büntetőeljárás hatékonyságának elemzése komplex feladat, véleményem szerint a Be. hatályba lépésétôl számítva minimum 5 évnek el kell telnie ahhoz, hogy következtetéseket vonhassunk le az új büntetőeljárási kódex eljárást gyorsító intézkedéseivel kapcsolatban. Mindazonáltal megítélésem szerint a büntetőeljárási kódex talán legfontosabb újításaként aposztrofált előkészítő ülés jogintézménye mellett a különleges bánásmód és „távmeghallgatás" szabályai is számottevően javíthatnak ezen mutatón.

\section{Különleges bánásmód biztosítása a büntetőeljárásban}

A büntetőeljárás szabályozásában az utóbbi évtizedekben egyre hangsúlyosabb szerepet kapott az egyéniesítés lehetősége, a büntetőeljárásban részt vevő személy egyedi igényeinek figyelembevétele, emellett ezen a területen a büntetőeljárásról szóló törvénynek számos nemzetközi kötelezettségnek is eleget kell tennie. ${ }^{20}$ Mindezen körülmények, továbbá a korszerüség, koherencia kodifikálási irányelvei indokolttá tették a szabályok átstrukturálását, egy átfogó, jogalkalmazást könnyítő rendszer bevezetését.

Ennek érdekében a jogalkotó a Be. XIV. fejezetében ${ }^{21}$ igyekszik egy helyen szabályozni a különleges bánásmóddal kapcsolatos rendelkezéseket, mindazonáltal a csoporthoz tartozó személyek jogai nemcsak ebben a fejezetben találhatók, hanem a törvény más helyein is, sőt, a gyermek- és tanúvédelemmel kapcsolatos rendelkezések magán a kódexen is túlmutatnak, mivel azon kívül más jogszabályok ${ }^{\mathbf{2 2}}$ is tartalmaznak ilyen intézkedéseket.

Cikkemben a terjedelmi korlátokra való tekintettel nem ismertetem ezen jogintézmény összes részletszabályát, csupán az általam hangsúlyosnak tartott fontosabb szabályokra, változásokra koncentrálok.

3.1. A különleges bánásmódot igénylő személyek köre. A Be. különleges bánásmódot rendező új szabályai az Európai Parlament és a Tanács bűncselekmények áldozatainak jogaira, támogatására és védelmére vonatkozó minimumszabályok megállapításáról és a 2001/220/IB tanácsi kerethatározat felváltásáról szóló 2012. október 25-i 2012/29/EU irányelvének átültetésén alapulnak, alapvetően tehát áldozatvédelmi funkciót töltenek be. ${ }^{23}$

Ám ezen funkció mellett, a Be. a korábbi szabályozáshoz képest jelentősen bővíti a különleges bánásmódot igénylő személyek körét, mivel a sértetten kívül a tanút is bevonja a védelemben részesíthetők körébe. ${ }^{24}$

${ }^{20}$ A büntetőeljárásról szóló T/13972. számú törvényjavaslat miniszteri indokolása, Budapest, 2017. február, 358. oldal

${ }^{21} \mathrm{~A}$ büntetőeljárásról szóló 2017. évi XC. törvény 81-96-§-a

${ }^{22}$ A fogyatékos személyek jogairól és esélyegyenlőségük biztosításáról szóló 1998. évi XXVI. törvény, a gyermek jogairól szóló, New York-i egyezmény kihirdetéséről szóló 1991. évi LXIV. törvény

${ }^{23}$ Dr. Belegi József (szerk.): Büntetőeljárás jog, Kommentár a gyakorlat számára, HVG-ORAC, Budapest, 2018, 214. oldal

${ }^{24}$ Be. 81 . § (1) bekezdés 
A fentiek mellett a büntetőeljárásban más résztvevők is érintettek lehetnek egyes intézkedések alkalmazásával, attól függetlenül, hogy nem tekinthetők különleges bánásmódot igénylő személynek, ezért a büntetőeljárási törvény bizonyos esetben a terhelt (például 18. életévét be nem töltött; fogyatékos személy) és más személyek számára is biztosítja a különleges bánásmód intézményrendszere egyes eszközeinek alkalmazhatóságát. ${ }^{25}$ Ilyen más személyként nevesíti a törvény a védőt, a szakértőt, a szaktanácsadót, a vagyoni érdekeltet, valamint, mindezek, továbbá a sértett és tanú segítőit. 26

Tekintettel arra, hogy a különleges bánásmód célja az érintett eljárási részvételének valamilyen szempontból akadályozott voltának kompenzálása, helyesnek tartom azon jogalkotói döntést, amely a különleges bánásmóddal érintett személyek körét jelentősen kibővítette. A gyakorlatban előfordul, hogy egy terhelt az ügyben részt vevő más terheltnek kiszolgáltatott, továbbá az is, hogy a terhelt a sértett vagy sértett hozzátartozói által kerül fenyegetett helyzetbe. Az ilyen esetek elkerülése, kezelése abban az esetben lehetséges, ha a büntetőügyben eljáró nyomozó hatóság, ügyészség, bíróság a terhelt tekintetében is alkalmazhatja a különleges bánásmód körébe tartozó kíméleti eszközöket. Hozzáteszem, megítélésem szerint egy többvádlottas ügy bizonyítását is megkönnyíti, ezáltal a büntetőeljárás hatékonyságának javítását eredményezi, ha a bíróság a terheltek "gyenge láncszemét" annak indokoltsága esetén különleges bánásmódban részesíti és adott esetben vádlott-társaitól elkülönítve, telekommunikációs eszközön keresztül foganatosítja a kihallgatását.

3.2. A különleges bánásmód megállapítása és visszautasítása. A különleges bánásmód megállapításának általános követelményei a korábbi szabályokkal azonosak, azokat változatlanul a személyes jellemzők vagy az eljárás tárgyát képező búncselekmény jellege és körülményei határozzák meg. A Be. - a jogalkalmazó számára az eddigieknél konkrétabb iránymutatásokat adva - példálózó jelleggel felsorolja azon szempontokat (életkor; szellemi, fizikai, egészségi állapot; eljárás tárgyát képező cselekmény kirivóan erőszakos jellege; érintett személy és a büntetőeljárásban részt vevő más személy viszonya), melyek megteremthetik a különleges bánásmód szabályrendszerének alkalmazását. ${ }^{27}$

A különleges bánásmód megállapítására hivatalból, vagy az érintett, továbbá az általános szabályokra figyelemmel az érintett segítőjének indítványára kerülhet sor. ${ }^{28}$ Koncepcionális változás, hogy míg az eddigi rendelkezések a jogalkalmazóra bízták olyan eljárási módszerek, protokollok kialakítását, amelyek lehetővé teszik a sértett fokozott védelmi igényének felmérését, meghatározását, addig az új Be. hatályba lépésével ezen döntésre egyéni értékelés alapján kerül sor, melynek tartalmát és formáját más jogszabály határozza meg. ${ }^{29}$

\footnotetext{
${ }^{25}$ Be. 82 . § a) és b) pont

${ }^{26}$ Kiss Anna: A különleges bánásmódot igénylő személyek jogai az új büntetőeljárási törvényben In: Kriminológiai tanulmányok 55. kötet (szerk.: Vókó György), Budapest, 2018, 105. oldal

${ }^{27}$ Be. 81 . § (2) bekezdés

${ }^{28}$ Dr. Belegi József (szerk.): i.m. 216. oldal

${ }^{29}$ Az egyes büntetőeljárási cselekményekre és a büntetőeljárásban részt vevő személyekre vonatkozó szabályokról szóló 12/2018. (VI.12.) IM rendelet
} 
A kódex az adminisztratív terhek minimalizálása végett úgy rendelkezik, hogy sem a különleges bánásmód megállapításáról, sem az e körbe tartozó egyes intézkedések alkalmazásáról szóló döntés nem igényel határozati formát, a döntés megtestesül magában az intézményrendszer alkalmazásában. ${ }^{30} \mathrm{~A}$ törvény a formakényszer minimalizálásával az intézmény rugalmas, az érintett személy és az eljáró bíróság, ügyészség, nyomozó hatóság együtttműködésén alapuló alkalmazását hangsúlyozza, csupán a sértett különleges bánásmód megállapítása iránt előterjesztett indítványának elutasításához követeli meg határozat hozatalát. Ennek indoka, hogy egyedül ezen döntés támadható jogorvoslattal.

A Be. rendelkezései speciális alanyi kört is nevesítenek, amely mindössze minimális - életkorra, fogyatékosságra, ügy tárgyára kiterjedő - vizsgálatot igényel a különleges bánásmódban részesítés szempontjából. E szerint külön döntés nélkül különleges bánásmódot igénylő személy a sértett, a tanú, ha tizennyolcadik életévét nem töltötte be, a fogyatékos személy és az is, aki ilyennek minősülhet, valamint a nemi élet szabadsága és a nemi erkölcs elleni büncselekmény sértettje. ${ }^{31}$ Ezzel kapcsolatban megjegyzendő, hogy a Be. a személyi kör kiszélesítése mellett, az életkoron alapuló vélelmet kizárólag az aktuális életkorra szúkítette, amely alapján előfordulhat, hogy a nyomozás elrendelésekor 18. életévét be nem töltött sértett tanúkihallgatását a nyomozó hatóság a kíméleti rendelkezések kötelező alkalmazása mellett folytatta le, ugyanakkor a nyomozás előrehaladtával - az említett életkort betöltve - már nincs törvényi kötelezettség a különleges bánásmód tekintetében szóba jöhető intézkedésekre. ${ }^{32}$

Ezen alanyi körrel kapcsolatban kiemelném, hogy bár a törvény szerint az eljáró szerveknek kötelező ezen esetekben a különleges bánásmód alkalmazása, a „fogyatékos személynek minősülhet"33 kitétel alapján az eljáró bíróság, ügyészség, nyomozó hatóság saját mérlegelése alapján, különleges szakértelmet igényló vizsgálat nélkül is alkalmazhatja a különleges bánásmód körébe tartozó intézkedéseket, ezzel a törvény teret enged ezen területen is a hatóság diszkrecionális jogkörének.

A különleges bánásmódot igénylő személy akaratának, önrendelkezési jogának teljes körű érvényesülését kívánja biztosítani, hogy az érintett a különleges bánásmód megállapítását, vagy egyes intézkedések alkalmazását bármikor visszautasíthatja. A törvény ez esetben sem ír elő formakényszert, ezzel is hangsúlyozva az együttmúködés fontosságát. Mindazonáltal, a kódex egyes esetekben az érintett akaratától független, kötelező eljárásjogi rendelkezéseket tartalmaz, amely visszautasítására nem kerülhet sor. ${ }^{34}$ Így nem utasítható vissza, hogy a 18. életévét be nem töltött sértett vagy tanú részvételét igénylő eljárási cselekményről kép- és hangfelvétel készüljön, továbbá ez indokolja azt is, hogy az eljáró szerv a különösen védett tanú személyét érintő eljárási cselekmények

\footnotetext{
${ }^{30}$ Be. 81. § (5) bekezdés

${ }^{31}$ Be. 82. § bekezdés

32 Dr. Lencse Balázs: Specifikus védelmi szükséglet, avagy különleges bánásmód az uniós normáktól az új büntetőeljárási kódexig, In: Büntetőjogi Szemle 2018/2. szám, 71. oldal

${ }^{33}$ Be. 82. § b) pont

${ }^{34}$ Be. 83 . § bekezdés
} 
jelenléttel kapcsolatos szabályaitól még a különösen védett tanú hozzájárulásával sem térhet el.

3.3. A különleges bánásmódhoz tartozó intézkedések. A különleges bánásmód szabályozásának alapeleme a fokozatosságra épülő eszközrendszer kialakítása ${ }^{35}$, a büntetőeljárási törvény ennek megfelelően gyüjtötte össze és alakította át a régi büntetőeljárási törvényben lévő jogintézményeket.

A fokozatosság az egyéniesítést, az akadályoztatás felszámolását biztosító intézmények két csoportjában jelenik meg:

a) jogérvényesítést, kíméletet célzó eszközök

b) védelmi eszközök.

A kíméleti eszközök az eljárás menetét érdemben kevésbé érintő intézmények, alapvetően az eljáró szervektől várják el, hogy átlag feletti körültekintéssel járjanak el. Ezen intézményrendszer szabadabban alkalmazható, nem teljesen zárt, a törvényben felsorolt eszközök mellett nem kizárt az érintett igényeire figyelemmel más megoldások alkalmazása sem.

A második csoportba tartozó eszközök adott esetben más eljárási résztvevő jogkorlátozásával járhatnak élet, testi épség, személyes szabadság veszélyeztetése esetén, illetve annak érdekében, hogy az érintett törvényes jogait és kötelességeit megfélemlítés nélkül és befolyásmentesen gyakorolhassa, teljesíthesse. Ezen eszközrendszer lényegesen kötöttebb, alkalmazásuk törvényi feltételhez kötött.

Jelen cikk nem vállalkozik a fent említett csoportokba tartozó konkrét intézkedések bemutatására, ám az általam hangsúlyozott hatékonyság kodifikációs alapelvére is tekintettel fontosnak tartom kiemelni, hogy a különleges bánásmód eszközrendszerét minden esetben úgy kell alkalmazni, hogy az a lehető legnagyobb mértékben szolgálja az érintett kíméletét és védelmét, ugyanakkor az alkalmazás egyáltalán ne, vagy a lehető legkisebb mértékben veszélyeztesse az eljárás eredményességét. Mivel a felderítés hatékonysága nagyban függ az időszerűségtől, hiszen egy akut esemény kapcsán az emlékezetnek és az azt torzító folyamatoknak nagy szerepe van, így a büntetőeljárásban a bünüldöző szerv haladéktalan, minél részletesebb információgyüjtése, illetve a különleges bánásmódban részesített személyek mindenekfelett álló érdeke, kímélete, védelme azonos hangsúllyal kell jelen legyen. ${ }^{36}$ Tekintettel arra, hogy a különleges bánásmódot igénylő sértettek esetén az érintett személy részvételét igénylő eljárási cselekményt úgy kell előkészíteni, hogy az megismétlés nélkül elvégezhető legyen, így a más rendőri eszközökkel történő hatékony információgyüjtés szerepe felértékelődik, hiszen a nyomozó hatóságnak a sértett kihallgatásakor minél pontosabb információkkal kell rendelkeznie.

Megítélésem szerint ezen eszközrendszer bizonyos elemeinek telekommunikációs eszközzel közös alkalmazása a büntetőeljárás gyorsítását, költségeinek jelentős

\footnotetext{
35 A büntetőeljárásról szóló T/13972. számú törvényjavaslat miniszteri indokolása, Budapest, 2017. február, 361. oldal

36 Szatmári Adrienn: A különleges bánásmódot igénylő sértettek meghallgatásának bünüldözési lehetőségei és tapasztalatai a rendőrségi eljárásokban, In: A bűnüldözés és a bűnmegelőzés rendészettudományi tényezői, Pécsi Határór, Tudományos Közlemények, 21. kötet, 2019, 183. oldal
} 
csökkentését is eredményezheti, ezen összefüggésre egy későbbi fejezetben kívánok rávilágítani.

\section{Telekommunikációs eszköz alkalmazása}

A zártcélú távközlő hálózat útján történő tárgyalás tartásának lehetőségét hazánkban a büntetőeljárásról szóló 1998. évi XIX. törvény módosítása kapcsán született 2002. évi I. törvény 146 . §-a iktatta be a Be. 2003. július 1 . napjától hatályba lépett szabályai közé. A jogintézmény bevezetését a tanú- és áldozatvédelem előtérbe kerülése indokolta, ám jelentős szerepe volt benne a határokon átívelő bünözés elleni harcnak, továbbá az eljárás lehető leggyorsabb és biztonságosabb lebonyolításához füződő érdeknek. ${ }^{37}$

A zártcélú távközlő hálózatok nemzetközi szinten is széles körben elterjedtek, az alkalmazásukban rejlő lehetőségek miatt népszerüségnek örvendenek. Jól mutatja ezt azon adat, hogy az Egyesült Királyságban a 2016-2017 közötti időszakban összesen 137000 esetben éltek a távtárgyalás lehetőségével. ${ }^{38} \mathrm{~A}$ jogintézmény sikerét jelzi az is, hogy a távtárgyalás rendszerét kiterjesztették néhány polgári jogi tárgyalásra is. ${ }^{39}$

Minden bizonnyal ezen hálózatok nemzetközi sikeressége is szerepet játszott abban, hogy a büntetőeljárási kódex a zártcélú távközlési eszköz útján történő tárgyalás szabályait jelentősen kiterjesztve lehetővé tette azt, hogy a tanú és terhelt kihallgatásán kívül más eljárási cselekményt is ilyen módon foganatosítson a büntető ügyben eljáró hatóság. A korszerűség, időszerűség, költséghatékonyság, a büntetőeljárásban részt vevő személyek védelmének kiemelt támogatása mellett a telekommunikációs eszközök használata a büntetőeljárási garanciák sérelmével nem jár, az a terhelt tárgyaláshoz való jogát is érvényre juttatja. ${ }^{40}$

4.1. Telekommunikációs eszköz használatának főbb szabályai. A büntetőeljárási törvény mind a jogintézmény elnevezésén (zártcélú távközlési eszköz $\rightarrow$ telekommunikációs eszköz), mind alkalmazási körén változtat, használatának lényege a következő: telekommunikációs eszköz használatának van helye

- az eljárás bármely szakaszában (nem csupán a vádemelés után, hanem a nyomozás során is),

- a büntetőeljárásban részt vevő bármely személy vonatkozásában (nem csak a terhelt és tanú tekintetében) és

${ }^{37}$ Bogotyán Róbert: Telekommunikációs eszközök alkalmazása a büntetés-végrehajtásban, In: Börtönügyi Szemle 2018/4. szám, 16. oldal

38 O. Bowcott: Videolinks in court trials undermine justice system, says report; https://www.theguardian.com/law/2017/oct/23/videolinks-in-court-trials-undermine-justicesystemsays-report (Megtekintés ideje: 2019. november 25.)

${ }^{39}$ HM Courts \& Tribunals Service, Ministry of Justice. (2018). Video hearing pilot launched.

https://www.gov.uk/government/news/video-hearing-pilot-launched (Megtekintés ideje: 2019. november 25.)

${ }^{40}$ Dr. Belegi József (szerk.): i. m. 302. oldal 
- akár az eljárási cselekmény egész időtartamára is (nem csupán a kihallgatás idejére). ${ }^{41}$

A kódex mindössze egyetlen lényeges korlátot állít fel a telekommunikációs eszköz használatával kapcsolatban azzal, hogy az előkészítő ülésen, valamint a személyi szabadságot érintő bírói engedélyes kényszerintézkedés elrendelése tárgyában tartott ülésen történő terhelti jelenlét biztosítására csak abban az esetben rendelhető el telekommunikációs eszköz használata, ha ahhoz a terhelt hozzájárul. ${ }^{42}$

A telekommunikációs eszköz használata kép- és hangfelvételt biztosító eszköz vagy folyamatos hangfelvétel útján történik, utóbbi azonban csak a tolmács jelenlétének biztosítása, vagy meghatározott eljárási cselekmény foganatosítása során használható. ${ }^{43}$

Változatlan az eljárási cselekmény technikai megoldása: két helyszínen - az eljárási cselekmény kitűzött helyszínén és az ettől elkülönült más helyiségben, illetve helyszínen zajlik. Fontos változás, hogy jelen szabályok alapján a bíróság részéről bírón kívül bírósági titkár vagy fogalmazó is elégséges az eljárási cselekmény hitelességének biztosításához, továbbá, ha az elkülönített helyszínen kihallgatandó személy fogva van, a terhelt őrzését ellátó személy is elláthatja ezen feladatokat. ${ }^{44}$

\subsection{A telekommunikációs eszköz és a különleges bánásmód} alkalmazásának kapcsolódása. A Be. rendelkezései alapján a bíróság, az ügyészség vagy a nyomozó hatóság hivatalból, illetve az eljárási cselekményen jelenlétre kötelezett vagy jogosult személye által előterjesztett indítványra rendelheti el a telekommunikációs eszköz használatát. ${ }^{45} \mathrm{~A}$ törvény ezen eszközök használatát alapvetően a büntetőeljárásban részt vevő hatóságok diszkrecionális döntéseként határozza meg, azok szabad belátásuk szerint dönthetnek az eszköz használatának elrendelése felöl.

Ám mindezek mellett a törvény nevesít olyan eseteket, amikor főszabályként telekommunikációs eszközt kell használni, ugyanakkor annak lehetőségét is megteremti, hogy meghatározott okokból, vagy az elérni kívánt eljárási cél más módon történő biztosításával a szigorú törvényi előírásoktól el lehessen térni. Ez alapján, ha az eszköz technikai feltételei fennállnak, az ügyészség és a nyomozó hatóság csak kivételes esetben mellőzheti az eszköz használatát

- különleges bánásmódot igénylő sértett jelenlétét igénylő eljárási cselekmény esetén,

- fogva lévő, személyi védelem alatt álló, vagy Védelmi Programban részt vevő tanú vagy terhelt jelenlétét igénylő cselekmény esetén. ${ }^{46}$

A kötelezően meghatározott esetek köre a bíróság előtti eljárásban kiegészül a letartóztatás meghosszabbítása, vagy fenntartása tárgyában tartott ülés esetkörével. ${ }^{47}$

\footnotetext{
${ }^{41}$ Be. $120 . \S$

42 Be. 122. § (5) bekezdés

${ }^{43}$ Be. 120. § (2)-(3) bekezdés

${ }^{44}$ Be. 123 . §

${ }^{45}$ Be. 121. §

${ }^{46}$ Be. 122. § (1) bekezdés

${ }^{47}$ Be. 122 . § (3) bekezdés c) pont
} 
Véleményem szerint a cikkemben vizsgált két jogintézmény szervesen kapcsolódik egymáshoz, a telekommunikációs eszköz használata fontos a különleges bánásmód szabályrendszere által meghatározott célok - egyéniesítés, büntetőeljárásban részt vevő személy egyedi igényeinek figyelembevétele eléréséhez. Ezen kapcsolódást ösztönzi a jogalkotó azáltal, hogy a különleges bánásmódot igénylő sértett jelenlétét igénylő eljárási cselekmény, a személyi védelem alatt álló, vagy Védelmi Programban részt vevő tanú vagy terhelt jelenlétét igénylő eljárási cselekményen is kvázi kötelezővé teszi a telekommunikációs eszköz használatát. Ennek indoka a védelem alatt álló személyek kímélete a tárgyaláson való jelenléttől, a terhelttel, terhelttársakkal való személyes találkozástól, ám megítélésem szerint ez a bizonyítás megkönnyítése által büntetőeljárás hatékonyságát, megalapozottságát is javíthatja.

További kapcsolódási pontként rögzíthető, hogy a bíróság, az ügyészség és a nyomozó hatóság a különleges bánásmódot igénylő személy védelme érdekében telekommunikációs eszköz használata esetén elrendelheti az érintett személy személyazonosságának megállapítására alkalmas egyedi tulajdonságok technikai eszközzel történő torzítását ${ }^{48}$, valamint az is, hogy ha a nemi élet szabadsága és nemi erkölcs elleni büncselekmény sértettje a 18 . életévét nem töltötte be, telekommunikációs eszköz alkalmazása során biztosítani kell, hogy a sértett kizárólag az eljáró bírót, ügyészt vagy nyomozó hatóság tagját láthassa. ${ }^{99}$

A különleges bánásmód szabályrendszerét a korábbiakban már elemeztem, azonban itt is külön kiemelést érdemel, hogy a 18. életévét be nem töltött sértett, illetve tanú pusztán életkori sajátossága alapján különleges bánásmódot igénylö személynek minősül.

Speciális eset merül fel, ha a nemi élet szabadsága és nemi erkölcs elleni büncselekmény sértettje a 18. életévét nem töltötte be, ekkor ugyanis a bíróság, az ügyészség és a nyomozó hatóság az eljárási cselekményről kép- és hangfelvételt köteles készíteni. Ilyen sértett esetében a fentiekben is leírtak szerint ügyelni kell arra, hogy a telekommunikációs eszköz alkalmazása során a sértett kizárólag az eljáró bírót, ügyészt, nyomozó hatóság tagját láthassa, továbbá az eljárási cselekményt az erre szolgáló, vagy arra alkalmassá tett helyiségben kell elvégezni, kivéve, ha az eljárási cselekmény ott nem hajtható végre, vagy a sértett jogai gyakorlásának, kötelezettségei teljesítésének elősegítése és kímélete, illetve védelme más módon is biztosítható. Megítélésem szerint a jelenlegi bírósági rendszerben a sértett jogai gyakorlásának elősegítése, kímélete, védelme telekommunikációs eszköz útján történő kihallgatása során is biztositható, nem szükséges az eljárási cselekménynek erre szolgáló helyiségben történő elvégzése, illetve ezen eszköz helyettesítheti a kiküldött bíró, vagy megkeresett bíróság útján történő kihallgatást. Amennyiben a bíró biztosítja, hogy a sértett egy másik tárgyalóteremben vele azonos nemü bírósági alkalmazottal tartózkodik és kihallgatása során csak a bírót látja, valamint kérdéseket is csak a bíró tesz fel neki, véleményem szerint ezzel is biztosítható a sértett kímélete.

\footnotetext{
${ }^{48}$ Be. 86. § (2) bekezdés a) pont

${ }^{49}$ Be. 89 . § (4) bekezdés d) pont
} 
Végezetül meglátásom szerint a cikk tárgyát képező jogintézmények közös alkalmazása nem csupán a büntetőeljárást segítheti, azzal a gyermekbarát igazságszolgáltatás jelentős eljárási garanciája, a meghallgatások számának minimalizálása, szakszerűsége is megvalósítható. Rendszeres eset ugyanis, hogy egy gyermek közigazgatási hatósági, polgári peres és büntetőeljárásokban egyaránt érintett, ahol hasonló tartalmú meghallgatások, vizsgálatok egymástól elkülönülve, egymásról mit sem tudva zajlanak..$^{50} \mathrm{Az}$ nyilvánvaló, hogy a büntetőeljárási garanciák okán az érintett gyermek meghallgatása a büntetőügyben eljáró hatóságok kötelessége, ám annak akadályát nem látom, hogy az erről telekommunikációs eszköz útján rögzített felvétel a gyermek és törvényes képviselője hozzájárulása esetén megküldhető legyen egyéb hatóságoknak. Ezen multidiszciplináris együttműködés esetén elkerülhető lenne a gyermek újabb traumatizálódása, másodlagos áldozattá válása.

\subsection{A jogintézmény gyakorlati tapasztalatai a Miskolci Törvényszéken}

\section{Távmeghallgatások a Miskolci Törvényszéken (2019)}

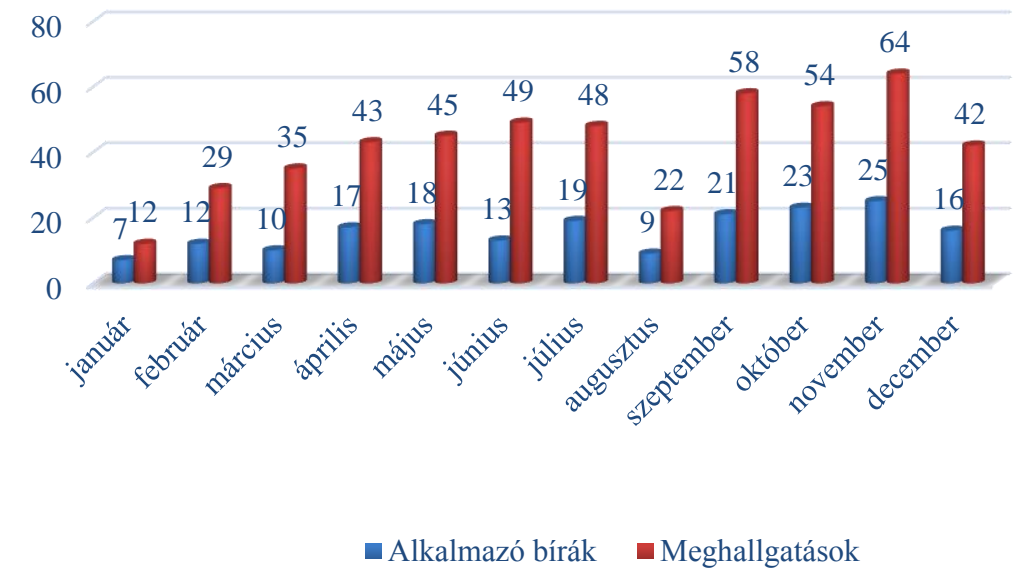

2. ábra Távmeghallgatások a Miskolci Törvényszéken 2019. évben (saját szerkesztés)

${ }^{50}$ Dr. Solt Ágnes: A „gyermekbarát igazságszolgáltatás” repedéseiről, In: Kriminológiai tanulmányok 55. kötet (szerk.: Vókó György), Budapest, 2018, 56. oldal 


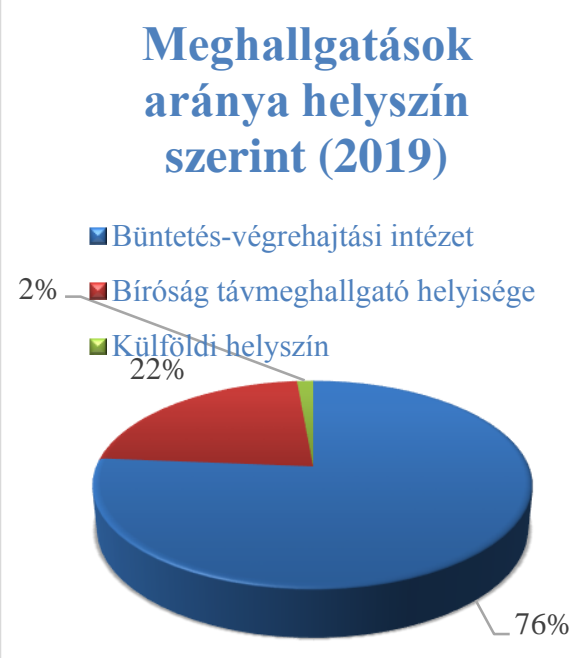

3. ábra Meghallgatások aránya helyszín szerint 2019. évben (saját szerkesztés)
Meghallgatott személyek aránya eljárási pozíció szerint (2019)

- gyanúsított/ vádlott/elítélt

- polgári peres fél

- tanú (minden ügyszak)

- szakértő (minden ügyszak)

$9 \% 0 \%$

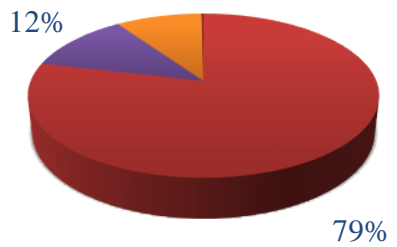

4. ábra Meghallgatott személyek száma eljárási pozíció szerint 2019. évben (saját szerkesztés)

A fenti ábrákból fontos következtetésként levonható, hogy a távmeghallgatás jogintézménye egyre nagyobb népszerüségnek örvend, a 2019. augusztusi, ítélkezési szünettel magyarázható visszaesést kivéve mind az azt alkalmazó bírák száma, mind a meghallgatások száma növekvő tendenciát mutat. Fontosnak tartom kiemelni, hogy bár 2020. évre vonatkozó összefoglaló statisztika nem áll rendelkezésemre, de nagyságrendileg rögzíthető, hogy 2020. végén havonta körülbelül 150-200 távmeghallgatást foganatosítottak a Miskolci Törvényszék területén. Nyilvánvaló, hogy ezen adat részben az évet meghatározó világjárvány következménye, ám azt is szükséges rögzíteni, hogy amennyiben az új büntetőeljárási törvény nem terjesztette volna ki a telekommunikációs eszköz alkalmazhatósági körét és az Országos Bírósági Hivatal nem építette volna ki azt ezt szolgáló infrastrukturális hátteret, úgy a tavalyi évben a személyi szabadságot érintő bírói engedélyes kényszerintézkedés hatálya alatt álló terheltekkel kapcsolatos eljárások járványügyi intézkedéseknek megfelelő lefolytatása is komoly problémát okozott volna.

A Miskolci Törvényszék területén a 2019-es évben a büntetés-végrehajtási intézetekkel 383, a bíróság távmeghallgató helyiségével 112, míg egyéb helyszínnel (külföldi helyszín, rendőrkapitányság, Igazságügyi Megfigyelő és Elmegyógyító Intézet) összekapcsolódva 7 távmeghallgatás történt. 394 alkalommal gyanúsított, vádlott, vagy elítélt, 59 alkalommal polgári peres fél, 48 esetben tanú, 1 esetben szakértő meghallgatására került sor.

Érdekességként megvizsgáltam, hogy a 2019 utolsó negyedévében (októberdecember) megtartott távmeghallgatások mekkora hányadát tették ki a büntetésvégrehajtási bírói és nyomozási bírói eljárások. Ennek során megfigyelhető, hogy az összes távmeghallgatás (160) több, mint felét ezen ügycsoportok tekintetében 
tartották a Miskolci Törvényszéken, a büntetés-végrehajtási bírói eljárások száma 52, míg a nyomozási bírói eljárások száma 33 darab volt ezen időszakban. Megítélésem szerint ennek oka egyrészt abban keresendő, hogy büntetőeljárási kódexünk ezen esetkörben csak különösen indokolt esetben teszi lehetővé a telekommunikációs eszköz használatának mellőzését, másrészt belátható, hogy ezen eljárások esetén célszerű és ésszerü az eszköz alkalmazása. Annál is inkább, mivel ezen eljárások általában rövid időtartamúak, nem szükséges azokra tanúk, szakértők megidézése.

A Miskolci Törvényszék területén (megítélésem szerint országosan is ezen tendencia figyelhető meg) a távmeghallgatás jogintézményének legnagyobb haszonélvezője a büntetés-végrehajtási szervezet. A módszer hozzájárul a fogvatartás rendjének és biztonságának fenntartásához, hiszen a tárgyalásra történő előállítások száma hosszú távon jelentősen csökkenni fog. Emellett a módszer költséghatékony is, mivel a kör- és célszállításban érintett fogvatartotti létszám csökkentését eredményezi, továbbá az sem elhanyagolható tény, hogy a fogvatartottak egy része nem csak az elkövetett búncselekmények jellege és súlya, hanem magatartása miatt is veszélyes, így intézeten kívüli mozgatásuk nem csak a társadalomra, de az őket mozgató személyi állományra is kiemelt kockázati tényezőt jelent. ${ }^{51}$

Mindazonáltal a terhelt telekommunikációs eszköz útján történő jelenlétének biztosítása a gyakorlatban problémába ütközik, mivel egy hosszabb időtartamú tárgyalás az érintett végpontot hosszú időre, akár egy egész napra lefoglalhatja. A büntetés-végrehajtási intézetekben kialakított egyetlen végpont aznapi használatára feltehetőleg számos foglalás érkezik, így annak egész napra történő lefoglalása problémát okoz, a rendszer müködését nem szolgálja.

Az ábrákkal kapcsolatban kiemelném még, hogy 48 esetben tanú meghallgatására került sor, míg 5 alkalommal külföldi helyszínnel összekapcsolódva történt távmeghallgatás. Ezen adat azért lényeges, mert a büntetőeljárások elhúzódásának jelentős oka a tanúk meg nem jelenése ${ }^{52}$, és a jogintézmény megfelelő alkalmazása ezen ok előfordulását csökkentheti, továbbá a büntetőeljárás megalapozottságának mutatója is javulhat a bizonyítás megkönnyítése által.

\section{5. Összegzés}

Tanulmányomban a bevezetésben meghatározott cél („szimpátia elnyerése”) mentén elemeztem a különleges bánásmód és "távmeghallgatás" jogintézményét, mely során kiemelt figyelmet fordítottam a jogintézmények és jogalkotó által meghatározott kodifikációs célok (hatékonyság, gyorsaság, egyszerüség, korszerüség, koherencia, célszerüség) összefüggéseire.

A kodifikációs célok és a büntetőeljárási törvény egésze alapján egyértelmű, hogy a törvény a jogalkalmazóktól új szemléletet kíván, a társadalom elvárásainak

\footnotetext{
${ }^{51}$ Bogotyán Róbert i.m.: 24. oldal

52 Dr. Nagy Anita: Eljárást gyorsító rendelkezések a büntetőeljárás bírósági szakaszában, PHD értekezés, Deák Ferenc Állam- és Jogtudományi Doktori Iskola, Miskolc, 2007, 270. oldal
} 
megfelelően az eddigieknél sokkalta jobban előtérbe kerül a büntetőeljárás hatékonyságának javítása.

Az átalakuló szemlélet a társadalom igényeinek megfelelő fejlődés eredménye, tudomásul kell venni, hogy a büntetőeljárás hatékonysága kiemelt figyelmet érdemel. A legfontosabb, hogy mind a jogalkotó, mind a jogalkalmazó az eljárás gyorsítását az eljárási garanciák tiszteletben tartásával, mindenkor a megalapozottság, jogszerüség követelményének megfelelve igyekezzen elérni.

Megítélésem szerint mind a különleges bánásmód, mind a távmeghallgatás jogintézménye ezen kívánalomnak eleget tesz, együttes és külön-külön történő megfelelő alkalmazásuk által megvalósítható a büntetőeljárásban részt vevő személy kímélete, védelme és az eljárás hatékonyságának javítása is. 